\title{
HUBUNGAN PENGETAHUAN DAN SIKAP PERAWAT TERHADAP COPING STYLE DAN ANTICIPATORY GRIEF PADA ORANGTUA DENGAN ANAK KANKER YANG DI RAWATA DI RSU KABUPATEN TANGERANG
}

\author{
Ema Hikmah $^{1}$, Parta Suhanda ${ }^{1}$ \\ ${ }^{1}$ Jurusan Keperawatan Poletkkes Kemenkes Banten
}

\begin{abstract}
ABSTRAK
Orangtua yang memiliki anak dengan penyakit kanker akan mengalami proses berduka, orangtua yang terpuruk dan menyalahkan diri sendiri ketika mengetahui anaknya menderita penyakit kanker. Penelitian ini bertujuan untuk mengetahi bagaimana hubungan antara pengetahuan dan sikap perawata terhadap pola koping dan proses berduka pada anak dengan diagnose kanker. Penelitian ini merupakan penelitian analitik dengan desain penelitian cross sectional. Hasil penelitian menunjukkan Tidak ada hubungan yang signifikan antara sikap perawat dan coping style orangtua dengan $\mathrm{p}$ value $0,42(\alpha<0,05)$ dan tidak ada hubungan antara sikap perawat dengan anticiatory grief orangtua dengan anak kanker dengan p value $0,91(\alpha<0,05)$. Tidak ada hubungan yang signifikn antara pengetahun perawat dan coping style orangtua dengan $\mathrm{p}$ value $0,5(\alpha<0,05)$ dan tidak ada hubungan antara pengethauan perawat dengan anticiatory grief orangtua dengan anak kanker dengan $\mathrm{p}$ value $0,76(\alpha<0,05)$. Penelitian selanjutnya agar dapat melakukan penelitian lanjutan terkait coping style dan anticypatory grief dengan metoda yang berbeda dan jumlag sampel yang lebih banyak.
\end{abstract}

Kata kunci: Perawat, Pengetahuan, Sikap, coping style

Korespondensi: Ema Hikmah. E-mail: mamah_beera@ymail.com 


\section{PENDAHULUAN}

Fenomenaa yang terjadi saat ini semakin banyak anak yang menderita penyakit kanker. Orangtua yang memiliki anak dengan penyakit kanker akan mengalami proses berduka, karena penyakit kanker merupakan salah satu penyakit kronis yang memerlukan penanganan yang serius. Koping dan proses berduka pada setiap orangtua akan berbeda-beda. Mungkin ada yang mempunyai koping yang positif, bangkit dari keterpurukannya dan mulai menata diri untuk bersama-sama dengan anggota keluarga yang lain menghadapi dan merawat anak yang sakit tersebut. Tetapi ada juga orangtua yang terpuruk dan menyalahkan diri sendiri ketika mengetahui anaknya menderita penyakit kanker, orangtua yang seperti ini akan sulit untuk bisa merawat anaknya yang memerlukan perhatian yang lebih. Dalam Keadaan orangtua yang terpuruk seperti ini perawat berperan penting dalam membantu orangtua untuk mendapatkan pola koping yang positif.

Perawat yang bertugas khususnya di ruangan anak, harus memahami bahwa peran dan tanggungjawabnya adalah dapat membantu orangtua. Sesuai dengan filosofi keperawatan anak orangtua harus di berdayakan dan dilibatkan dalam melakukan perawatan pada anak. Sebelum orangtua mendapatkan informasi mengenai keadaan anaknya sebaiknya perawat menyiapkan orangtua agar mempunyai pola koping yang positif dan bisa melalui proses berduka dengan baik.

Keluarga berperan secara psikososial dengan membantu mengontrol perilaku anak dalam menghadapi perubahan fisik dan psikologis. Hal tersebut tersebut pernah pula diungkapkan oleh Newland (2008) bahwa hubungan orang tua dan anak secara langsung berpengaruh dengan kondisi sakit anak dan kemampuan mengatur perilaku terhadap perubahan yang terjadi selama sakit.

Sebagai seorang praktisi di bidang kesehatan, terutama kesehatan anak, peneliti berkeinginan untuk melakukan penelitian yang terkait dengan pengetahuan dan sikap perawat. terhadap orangtua dengan anak yang didiagnosa kanker. Berdasarkan dari paparan yang sudah

dikemukakan diatas, peneliti tertarik untuk melakukan penelitian dengan judul "Hubungan Tingkat Pengetahuan dan Sikap perawat terhadap Coping Style dan Anticipatory Grief pada Orangtua Anak Dengan Kanker di RSU Kabupaten Tangerang”.

\section{METODA}

Penelitian ini merupakan penelitian kuantitatif dengan menggunakan desain penelitian cross sectional. Data dianalisis menggunakan analisis bivariat chi-square.

Kegiatan penelitian ini menggunakan quesioner untuk melihat pengetahuan dan sikap perawata da quesioner pada orangtua bagaimana coping style dan anticipatory guidence.

\section{HASIL}

Hasil penelitian hubungan pengetahuan dan sikap perawat terhadap Coping style dan anticipatory grief orangtua dengan anak kanker di Rumah Sakit Umum Kabupaten Tangerang. Jumlah responden penelitian sebanyak 30 responden perawat dan 30 responden orangtua anak dengan kanker. Analisa univariat untuk menjelaskan karakteristik dari masing-masing variabel yang diteliti, analisa bivariat akan menjelaskan akan menguraikan ada tidaknya hubungan antara pengetahuan dan sikap perawat terhadap Coping style dan anticipatory grief orangtua dengan anak kanker di Rumah Sakit Umum Kabupaten Tangerang.

\section{Tabel 1}

Distribusi Responden berdasarkan Pengetahuan Perawat Tentang Perawatan Paliatif di Rumah Sakit Umum Kabupaten Tangerang tahun 2017

\begin{tabular}{ccc}
\hline Pengetahuan & Frekuensi & Persentase \% \\
\hline Tinggi & 18 & 60 \\
Rendah & 12 & 40 \\
\hline Total & 30 & 100 \\
\hline
\end{tabular}

Tabel 1. menunjukkan pengetahuan perawat tentang perawatan paliatif di RSU Tangerang. 30 orang responden memperlihatkan 
pengetahuan perawat dengan pengetahuan baik sebanyak 18 orang atau $60 \%$ dan pengetahuan perawat yang buruk tentang perawatan paliatif sebanyak 12 orang atau $40 \%$. Hasil tersebut memperlihatkan bahwa sebagian besar perawat mempunyai pengetahuan yang baik tentang perawatan paliatif di RSU Tangerang.

\section{Tabel 2}

Distribusi Responden berdasarkan Sikap Perawat Tentang Perawatan Paliatif di Rumah Sakit Umum Kabupaten Tangerang Tahun 2017

\begin{tabular}{ccc}
\hline Sikap & Frekuensi & Persentase \% \\
\hline Positif & 19 & 63 \\
Negatif & 11 & 37 \\
\hline Total & 30 & 100 \\
\hline
\end{tabular}

Tabel 2. menunjukkan sikap perawat tentang perawatan paliatif di RSU Tangerang dari 30 orang responden memperlihatkan sikap perawat yang positif sebanyak 19 orang atau $63 \%$ dan sikap perawat yang negatif tentang perawatan paliatif sebanyak 11 orang atau $37 \%$. Hasil tersebut memperlihatkan bahwa sebagian besar perawat mempunyai sikap yang positif tentang perawatan paliatif di RSU Kabupaten Tangerang.

\section{Tabel 3}

Distribusi Responden berdasarkan Coping Style Orangtua anak dengan kanker di RSU Tangerang tahun 2017

\begin{tabular}{ccc}
\hline Coping Style & Frekuensi & Persentase $\%$ \\
\hline Positif & 22 & 73 \\
Negatif & 8 & 27 \\
\hline Total & 30 & 100 \\
\hline
\end{tabular}

Tabel 3. menunjukkan coping style orangtua anak dengan kanker di Rumah sakit Umum Kabupaten Tangerang terhadap 30 orang responden memperlihatkan yang mempunya coping style yang positif sebanyak 22 orang atau $73 \%$, sedangankan responden yang mempunyai coping style yang negatif sebanyak 8 orang atau 27\%. Hasil ini menunjukkan bahwa sebagian besar responden mempunya coping style yang positif.

\section{Tabel 4}

Distribusi Responden berdasarkan Anticipatory Grief Orangtua anak dengan kanker di RSU Tangerang tahun 2017

\begin{tabular}{ccc}
\hline Antcipatory Grief & Frekuensi & Persentase \% \\
\hline Baik & 14 & 47 \\
Buruk & 16 & 53 \\
\hline Total & 30 & 100 \\
\hline
\end{tabular}

Tabel 4. menunjukkan anticipatory grief orangtua anak dengan kanker di Rumah sakit Umum Kabupaten Tangerang terhadap 30 orang responden memperlihatkan yang mempunya anticipatory grief yang baik sebanyak 14 orang atau $47 \%$, sedangankan responden yang mempunyai anticipatory grief yang buruk sebanyak 16 orang atau 53\%. Hasil ini menunjukkan bahwa sebagian responden mempunya anticipatory grief yang buruk .

\section{Tabel 5}

Hubungan Pengetahuan Perawat terhadap Coping Style Orangtua Anak dengan Kanker di RSU Tangerang Tahun 2017

\begin{tabular}{cccccc}
\hline Pengetahuan & \multicolumn{2}{c}{ Coping Style } & $\begin{array}{c}\text { Total } \\
\%\end{array}$ & OR & $\begin{array}{c}P \\
\text { value }\end{array}$ \\
& positif(\%) & $\begin{array}{c}\text { Negatif } \\
(\%)\end{array}$ & & & \\
\hline Tinggi & $14(78)$ & $4(22)$ & $18(100)$ & 1,75 & 0,5 \\
Rendah & $8(67)$ & $4(33)$ & $12(100)$ & & \\
\hline Total & $22(73)$ & $8(27)$ & $30(100)$ & & \\
\hline$* \alpha<0,05$ & & & & & \\
\hline
\end{tabular}

Dari Tabel 5 analisis hubungan pengetahuan perawat terhadap coping style orangtua anak dengan kanker di RSU Tangerang didapatkan hasil 14 orang atau $78 \%$ sedangkan pengetahuan perawat rendah dengan coping style orangtua yang negatif sebanyak 4 orang atau $33 \%$. 


\section{Tabel 6}

Hubungan Pengetahuan Perawat terhadap

Anticipatory Grief Orangtua Anak dengan

Kannker

di RSU Tangerang Tahun 2017

\begin{tabular}{cccccc}
\hline Pengetahuan & \multicolumn{2}{c}{ Anticipatory Grief } & $\begin{array}{c}\text { Total } \\
\%\end{array}$ & OR & $\begin{array}{c}P \\
\text { value }\end{array}$ \\
& baik(\%) & buruk $(\%)$ & & & \\
\hline Tinggi & $8(44)$ & $10(56)$ & $18(100)$ & 0,89 & 0,76 \\
Rendah & $6(50)$ & $6(50)$ & $12(100)$ & & \\
\hline Total & $14(47)$ & $16(53)$ & $30(100)$ & &
\end{tabular}

$* \alpha<0,005$

Dari Tabe 16. analisis hubungan pengetahuan perawat terhadap anticipatory grief orangtua anak dengan kanker di RSU Tangerang didapatkan hasil Pengetahuan perawat yang tinggi dengan orangtua yang anticipatory griefnya baik sebanyak 8 orang atau $44 \%$, sedangkan pengetahuan perawat rendah dengan anticipatory grief yang buruk sebanyak 6 orang atau $50 \%$.

\section{Tabel 7}

Hubungan Sikap Perawat terhadap Coping Style Orangtua Anak dengan Kanker di RSU Tangerang Tahun 2017

\begin{tabular}{cccccc}
\hline Pengetahuan & \multicolumn{2}{c}{ Coping Style } & $\begin{array}{c}\text { Total } \\
\%\end{array}$ & OR & $\begin{array}{c}P \\
\text { value }\end{array}$ \\
& positif(\%) & $\begin{array}{c}\text { Negatif } \\
(\%)\end{array}$ & & & \\
\hline Tinggi & $15(79)$ & $4(21)$ & $19(100)$ & 2,14 & 0,84 \\
Rendah & $7(64)$ & $4(36)$ & $11(100)$ & & \\
\hline Total & $22(73)$ & $8(27)$ & $30(100)$ & & \\
\hline$* \alpha<0,05$ & & & & & \\
\hline
\end{tabular}

Dari Tabel 7 analisis hubungan pengetahuan perawat terhadap coping style orangtua anak dengan kanker di RSU Tangerang didapatkan hasil Pengetahuan perawat yang baik dengan coping style orangtua yang positif sebanyak 15 orang atau $79 \%$, sedangkan pengetahuan perawat rendah dengan coping style yang negatif sebanyak 4 orang atau $36 \%$.
Tabel 8

Hubungan Sikap Perawat terhadap Anticipatory Grief Orangtua Anak dengan Kannker di RSU Tangerang Tahun 2017

\begin{tabular}{llcccc}
\hline Sikap & \multicolumn{2}{c}{ Anticipatory Grief } & $\begin{array}{c}\text { Total } \\
\%\end{array}$ & OR & $\begin{array}{c}P \\
\text { value }\end{array}$ \\
& baik(\%) & $\operatorname{buruk}(\%)$ & & & \\
\hline Positif & $9(47)$ & $10(53)$ & $19(100)$ & 1,08 & 0,01 \\
Negatif & $5(50)$ & $6(50)$ & $11(100)$ & & \\
\hline Total & $14(47)$ & $16(53)$ & $30(100)$ & & \\
\hline$* \alpha<0,05$ & & & & & \\
\hline
\end{tabular}

Dari Tabel 8. analisis hubungan pengetahuan perawat terhadap anticipatory grief orangtua anak dengan kanker di RSU Tangerang didapatkan hasil sikap perawat yang positif dengan anticipatory orangtua yang positif sebanyak 9 orang atau $47 \%$, sedangkan pengetahuan sikap perawat yang buruk dengan coping style yang negative sebanyak 6 orang atau $50 \%$.

\section{PEMBAHASAN}

\section{Gambaran pengetahuan perawat dan sikap tentang perawatan paliatif}

Hasil distribusi pengetahuan perawat tentang perawatan paliatif pada anak kanker menunjukkan bahwa sebagian besar perawat atau sekitar 18 orang (60\%) mempunyai pengetahuan yang tinggi tentang perawatan paliatif. Hal ini karena Rumah Sakit Umum Kabupataen Tangerang telah cukup lama atau sekitar 5 tahun menerima dan merawat pasien anak dengan kanker, dan RSU kabupaten Tangerang merupakan rumah Sakit rujukan di Provinsi Banten, sehingga yang dulunya pasien anak dengan kanker berobat ke RSCM Jakarta atau RS. Dharmais. Pengetahuan yang baik ini karena perawat telah mempunyai informasi yang baik dari tim kesehatan yang lain dan Rumah sakit telah melakukan pelatihan-pelatihan terkait dengan permasalahan kanker dan perawatan paliaif, karena Tingkat pengetahuan adalah 
tingkat berapa kedalaman seseorang dapat menghadapi, mendalami, memperdalam perhatian seperti sebagaimana manusia menyelesaikan masalah tentang konsep-konsep baru dan kemampuan dalam belajar. (Lestari, 2015).

Hasil distribusi sikap perawat tentang perawatan paliatif pada anak dengan kanker menunjukkan bahwa sebagian besar perawat atau 19 orang (63\%), mempunyai sikap yang positif. Semakin sering perawat memberikan asuhan keperawatan pada pasien kanker, maka perawat akan terlatih secara afektif dan konatif mempunyai sikap yang positif terhadap perawatan paliatif, karena seperti yang dikatakan oleh Lestari tahun 2015 bahwa, Sikap adalah proses penilaian yang dilakukan seseorang terhadap suatu obyek atau situasi yang disertai adanya perasaan tertentu dan memberikan dasar kepada orang tersebut untuk membuat respon atau kecenderungan untuk berperilaku dalam cara tertentu yang dipilihnya. Sikap adalah kecenderungan bertindak, berpikir, berpersepsi dan merasa dalam menghadapi objek, ide, situasi atau nilai. Sikap bukanlah prilaku, melainkan lebih merupakan kecenderungan untuk berprilaku dengan cara tertentu terhadap objek sikap. Objek sikap dapat berupa orang, benda, tempat, gagasan, situasi atau kelompok. (Alex Sobur, 2016)

Gambaran coping style dan anticipatory guidence pada orangtua anak dengan kanker Hasil distribusi coping style orangtua anak dengan kanker menunjukkan mempunyai sebagian besar posistif yaitu 22 orang atau $73 \%$. Coping style yang positif menunjukkan bahwa orangtua sudah mulai dapat menerima perubahan dalam kehidupan keluarga dengan kehadiran anaknya yang menderita kanker. Keluarga dengan anak kanker membutuhkan adaptasi yang baik terhadap perubahan yang terjadi, perubahan itu seperti anak dengan kanker harus mendapatkan pengobatan yang rutin karena beberapa anak harus diberikan pengobatan kemoterapi. Anak dengan kanker akan sangat tergantung pada orangtuanya karena dengan gangguan fisik maupun psikologis mengalami gangguan. Dengan kondisi seperti itu orangtua harus sudah dapat menyesuaikan diri atau beradaptasi dengan baik dengan perubahan yang terjadi. Sebagian orangtua menunjukkan pola coping style yang posistif. Coping didefinisikan sebagai upaya kognitif dan perilaku yang berubah secara konstan untuk mengelola tuntutan eksternal dan/ atau internal tertentu yang dinilai berat dan melebihi sumber daya (kekuatan) seseorang (Lazarus \& Folkman, 1984). Coping dapat juga dikatakan sebagai bentuk adaptasi karena coping merupakan bagaimana cara seseorang bereaksi terhadap sebuah stimulus yang didapat dari lingkungannya (Costa,Somerfield, \& McCrae, 1996 dalam Primaldhi 2006). Sejalan dengan Lazarus dan Folkman, Pearling dan Schooler, 1978 (dalam Ivancovich, 2004) mendefinisikan copingnsebagai tanggapan terhadap ketegangan hidup yang berfungsi untuk mencegah, menghindari, atau mengendalikan gangguan emosi.

Analiss hubungan pengetahuan perawat terhadap coping style dan anticipatory grief orangtua dengan anak kanker di RSU Kabupaten Tangerang

Hasil analisis menunjukkan bahwa hubungan pengetahuan perawat dengan coping style tidak signifikan atau Ho gagal di tolak dengan $\mathrm{p}$ value $0,5(\alpha<0,05)$, artinya tidak ada hubungan yang signifikan antara pengetahuan perawat dengan coping style orangtua anak dengan kanker. Pengetahuan perawat yang tinggi tidak mempengaruhi coping style orangtua, mungkin dikarenakan proses orangtua dapat mempunyai koping yang positif atau bisa beradaptasi dengan perubahan yang terjadi dapat dipengaruhi oleh banyak hal. Faktor yang mempengaruhi itu antara lain kesehatan fisik, keyakinan dan pandangan positif, keterampilan memecahkan masalah, keterampilan sosial dan dukungan sosial orangtua (Lazarus dalam Nasir 2004). Interaksi yang intens antara perawat dan orangtua anak dengan kanker dalam beberapa bulan terakhir mengalami hambatan dikarenakan perawatan dan pengobatan kemoterapi tidak bisa 
maksimal dilaksanakan di RSU Kabupaten Tangerang. Faktor lain yang dapat mempengaruhi antara lain sistem pembagian tugas perawat di ruangan anak masih menggunakan pembagian tugas tidak menggunakan primary nurse sehingga hal ini bisa mempengaruhi kedekatan hubungan antara perawat dengan orangtua dan anak dengan kanker.

Hasil analisis menunjukkan bahwa hubungan pengetahuan perawat dengan anticipatory grief tidak signifikan atau Ho gagal di tolak dengan $\mathrm{p}$ value $0,76(\alpha<0,05)$, artinya tidak ada hubungan yang signifikan antara pengetahuan perawat dengan anticipatory grief orangtua anak dengan kanker. Sikap perawat sebagian besar positif sedangkan anticypatory grief orangtua anak dengan kanker sebagian besar buruk. Padahal kalau di cermati coping style orangtua anak dengan kanker sebagian besar positif. Meskipun orangtua mempunyai coping style yang posistif tetapi ternyata sebagian besar masih mempunyai anticipatory grief yang buruk, artinya orangtua dapat beradaptasi dengan anaknya yang terkena kanker, bersemangat melakukan pengobatan dan perawatan tetapi belum/tidak siap menerima bahwa suatu saat akan kehilangan anaknya. Orangtua tetap optimis bahwa anaknya akan sembuh dan sehat kembali. Penelitian menunjukkan bahwa keluarga dan pengasuh menunjukkan reaksi yang bervariasi terhadap diagnosis penyakit terminal khususnya kanker yang meliputi tidak percaya, shock, bingung hampa, cemas akan masa depan, marah, tegang,depresi, kecewa, bahkan penerimaan dan harapan (Grbich, Maddocks, \& Parker, 2001; Young, Dixon-Woods, Findlay, \& Heney, 2002). Di samping harus berusaha mengatasi reaksi emosional yang mereka alami, orangtua tetap harus merawat dan terus memberi dukungan terhadap anaknya.

\section{Analiss hubungan sikap perawat terhadap coping style dan anticipatory grief orangtua dengan anak kanker di RSU Kabupaten Tangerang.}

Hasil analisis menunjukkan bahwa hubungan sikap perawat dengan coping style tidak signifikan atau Ho gagal di tolak dengan $\mathrm{p}$ value $0,42(\alpha<0,05)$, artinya tidak ada hubungan yang signifikan antara sikap perawat dengan coping style orangtua anak dengan kanker. Pemberian asuhan keperawatan khususnya keperawatan anak harus komprehensif bukan hanya pada anak yang menderita kanker tetapi juga pada orangtua atau keluarganya. Ketika anak mengalami sakit terutama sakit kronis seperti kanker maka tingkat ketergantungan anak pada orangtua sangat tinggi. Hasil univariat menunjukkan sebagian besar perawat mempunyai sikap yang positif tetapi tidak berpengaruh secara signifikan terhadap coping style orangtua anak dengan kanker. Hal ini harus menjadi perhatian bagi praktisi keperawatan, fokus perhatian pada perawatan paliatif bukan hanya masalah fisik yang mengalami gangguan tetapi masalah psikis anak da orangtua. Perawat merupakan tenaga kesehatan yang sangat penting dalam pemberian layanan pada pasien kanker, meskipun dalam pelaksanaannya banyak tenaga kesehatan yang harus berperan dalam pengobatan dan perawatan anak dengan kanker antara lain Perawat, dokter, psikolog, Care Giver, Rohaniawan, Ahli Gizi, Relawan dan Fisioterapis. Sehingga banyak tenaga kesehatan yang lain yang ikut berperan untuk menangani proses pengobatan dan perawatan anak kanker dan keluarganya.

Hasil analisis menunjukkan bahwa hubungan sikap perawat dengan anticipatory grief tidak signifikan dengan $p$ value $0,91(\alpha<0,05)$, artinya tida ada hubungan antara sikap perawat dengan anticipatory grief orangtua anak dengan kanker. Sikap perawat yang positif pada orangtua anak dengan penyakit kanker dapat mempengaruhi anticipatory grief yang positf. Sejak terdiagnosa penyakit kanker perawat harus sudah menyiapkan proses berduka orangtua. Orangtua harus sadar, faham dan mengerti dibalik perjuangan melawan penyakit kanker anaknya orangtua juga tetap harus menyiapkan diri, kapan saja dapat kehilangan anaknya. Orangtua yang memiliki anak dengan penyakit kanker menghadapi berbagai kesulitan biopsikososialspiritual sejalan dengan fase pengobatan yang dilalui anak mereka. Meskipun 
sikap perawat yang posistif dapat memiliki kecenderungan anticipatory grief yang baik (44\%), ternyata ada faktor lain yang sangat besar pengaruhnya terhadap anticipatory grief orangtua.

\section{KESIMPULAN}

Pengetahuan dan sikap perawat dalam perawatan paliatif, Pengetahuan perawat tentang perawatan paliatif di RSU Tangerang, menunjukkan pengetahuan perawat dengan pengetahuan baik sebanyak 18 orang atau $60 \%$ dan pengetahuan perawat yang buruk tentang perawatan paliatif sebanyak 12 orang atau $40 \%$. Sedangkan sikap perawat tentang perawatan paliatif di RSU Tangerang dari 30 orang responden memperlihatkan sikap perawat yang positif sebanyak 19 orang atau $63 \%$ dan sikap perawat yang negatif tentang perawatan paliatif sebanyak 11 orang atau $37 \%$. Coping style dan anticipatory grief orangtua dengan anak kanker di RSU Kabupaten Tangerang. Coping style orangtua anak dengan kanker menunjukkan coping style yang positif sebanyak 22 orang atau $73 \%$, sedangankan orangtua yang mempunyai coping style yang negatif sebanyak 8 orang atau $27 \%$. Sedangkan anticipatory grief orangtua anak dengan kanker menunjukkan yang mempunya anticipatory grief yang baik sebanyak 14 orang atau $47 \%$, sedangankan responden yang mempunyai anticipatory grief yang buruk sebanyak 16 orang atau 53\%. Hubungan pengetahuan perawat terhadap coping style dan anticipatory grief orangtua anak dengan kanker di RSU Kabupaten Tangerang.

Tidak ada hubungan yang signifikn antara pengetahun perawat dan coping style orangtua dengan $\mathrm{p}$ value $0,5(\alpha<0,05)$ dan tidak ada hubungan antara pengethauan perawat dengan anticiatory grief orangtua dengan anak kanker dengan $\mathrm{p}$ value $0,76(\alpha<0,05)$. Hubungan antara sikap perawat dalam perawatan paliatif terhadap coping style dan anticipatory grief orangtua anak dengan kanker di RSU kabupaten tangerang.

Tidak ada hubungan yang signifikn antara sikap perawat dan coping style orangtua dengan $\mathrm{p}$ value $0,42(\alpha<0,05)$ dan tidak ada hubungan antara sikap perawat dengan anticiatory grief orangtua dengan anak kanker dengan $\mathrm{p}$ value $0,91(\alpha<0,05)$.

\section{DAFTAR PUSTAKA}

Amanda. 2015. Dukungan orangtua yang memiliki anak dengan leukemia usia 6-12 tahun di

RSUKabupatenTangerang.http://reposit ory.uinjkt.ac.id/dspace/bitstream/12345 6789/30625/1/AMANDA\%20FEBRIA NI\%20PUTRI-FKIK.pdf Diakses Oktober 2016

Handayani, Dwi Sri (2008) Hubungan Antara Tingkat Pengetahuan dan Sikap dengan Perilaku Para Wanita Dewasa Awal Dalam Melakukan Pemeriksaan Payudara Sendiri Di Kelurahan Kalangan Kecamatan Pedan Klaten. Undergraduate thesis, Universitas Diponegoro. http://keperawatan.undip.ac.id Diakses Oktober 2016

Rahmania Q, Tuheteru ES. 2014. Hubungan Antara Coping Style dan Anticipatory Grief pada Orangtua dari Anak Dengan Diagnosis Kanker di Rumah Sakit Kanker

Dharmaishttp://www.indonesianjourna lofcancer.or.id/ejournal/index.php/ijoc/article/view/149. Diakses Oktober 2016

Rini AT, et al. 2009. Karakteristik Leukemia Limfoblastik Akut pada Anak di Rumah Sakit Kanker Dharmais 20002008.

http://indonesianjournalofcancer.or.id/e $=$

journal/index.php/ijoc/article/view/122. Diakses Oktober 2016 
Saadadiyah N, Sartika D. 2015. Hubungan Antara Dukungan Sosial Dengan Character Strength Orang Tua Dari Anak Penderita Kanker Di Rumah Cinta Bandung. http://karyailmiah.unisba.ac.id/index.p hp/psikologi/article/view/1184. Diakses Oktober 2016. 